\title{
Neem leaf utilization for copper ions removal from aqueous solution
}

\author{
Novie Febriana $^{a}$, Sisca O. Lesmana ${ }^{\text {a }}$, Felycia E. Soetaredjo ${ }^{\text {a }}$, Jaka Sunarso ${ }^{\mathrm{b}}$, Suryadi Ismadji ${ }^{\mathrm{a}, *}$ \\ ${ }^{a}$ Department of Chemical Engineering, Widya Mandala Surabaya Catholic University, Kalijudan 37, Surabaya 60114, Indonesia \\ ${ }^{\mathrm{b}}$ Division of Chemical Engineering, The University of Queensland, St. Lucia, Qld 4072, Brisbane, Australia
}

\section{A R T I C L E I N F O}

\section{Article history:}

Received 2 December 2008

Received in revised form 3 April 2009

Accepted 3 April 2009

\section{Keywords:}

Neem leaf

Adsorption

Heavy metal

\begin{abstract}
A B S T R A C T
Adsorption of copper onto neem leaf powder was studied in batch and continuous mode. Langmuir and Freundlich models were used to fit the equilibria data of which Langmuir model is considered better in correlation. The maximum adsorption capacity of neem leaf powder was $18.29 \mathrm{mg} / \mathrm{g}(0.288 \mathrm{mmol} / \mathrm{g})$. Column adsorption study to obtain the breakthrough curves was also presented on which Thomas model were chosen to represent the dynamic sorption data. Thermodynamics data indicated that the adsorption process is spontaneous, irreversible and endothermic.
\end{abstract}

(c) 2009 Taiwan Institute of Chemical Engineers. Published by Elsevier B.V. All rights reserved.

\section{Introduction}

Water pollution normally occurs by direct discharge of waste material or wastewater to surface water. Most significant problem in water pollution is largely caused by heavy metals. Heavy metal pollution originates from industrial wastewater namely electroplating, metal finishing, metallurgical, tannery, chemical manufacturing, mining and battery manufacturing industries (Aksu and Donmez, 2006; Al-Rub, 2006; Kang et al., 2007). Heavy metals' traces in industrial wastewater brings a potential problem onto human health, thus, their removal from wastewater is of particular importance.

A number of techniques are currently available to sequester heavy metals from industrial wastewater and adsorption onto activated carbon has become a quite common technique to treat industrial effluent containing heavy metals. Due to its uneconomic price, studies on alternative adsorbents have been intensified which focused mainly on biomass-based materials (Bhattacharyya and Sharma, 2004; Mungasavalli et al., 2007).

Numerous studies already utilized neem leaves as alternative sorbent to remove heavy metal such as $\mathrm{Pb}$ (Bhattacharyya and Sharma, 2004) and Cd (Sharma and Bhattacharyya, 2005). Copper is a heavy metal widely found in polluted water canal systems in some parts of East Java (Indonesia), mostly comes from incomplete wastewater treatment. In this paper, neem leaf's performance to adsorb $\mathrm{Cu}$ from aqueous solution is probed. Surface structures of neem leaf remains stable during long time agitation treatment,

\footnotetext{
* Corresponding author. Tel.: +62 313891264; fax: +62 313891267.

E-mail address: suryadiismadji@yahoo.com (S. Ismadji).
}

highlighting its advantage as adsorbents (Bhattacharyya and Sharma, 2004).

\section{Materials and methods}

\subsection{Materials}

Cupric sulfate hexahydrate, $\mathrm{CuSO}_{4} \cdot 6 \mathrm{H}_{2} \mathrm{O}$ (analytical grade) was purchased from Sigma-Aldrich (Singapore) and used as heavy metal model without any further treatment. Dried neem leaves collected from Probolinggo (East Java, Indonesia) were pulverized onto fine powder by grinding inside a mechanical grinder. The $\mathrm{pH}_{\mathrm{pzc}}$ of the neem leaf was determined from acid-based titration (Wibowo et al., 2007).

\subsection{Characterization of the neem leaf}

Characterization of biosorbent's surface and structure hold keys to understanding the metal binding mechanism onto biomass. Fourier transform infra-red (FTIR), energy-dispersive $\mathrm{X}$-ray spectroscopy and X-ray mapping were used here. FTIR spectroscopy technique was used to determine the functional groups available in neem leaf. FTIR spectrometer (Shimadzu 8400 s) equipped with $\mathrm{KBr}$ window were used to analyze neem leaf powder (wavenumber range: $400-4000 \mathrm{~cm}^{-1}$ ). SEM were performed using JEOLJSM-6400F field emission SEM. The observation of samples was conducted at an accelerating voltage of $10 \mathrm{kV}$, aperture of $4,37 \mathrm{~mm}$ working distance, and spot size of 8. Energydispersive X-ray and X-ray elemental mapping analysis was performed on JEOL JSM-6460 LA low vacuum analytical SEM equipped with an integrated JEOL Hyper mini-cup, $133 \mathrm{eV}$ 
resolution, SiLi crystal, ultra thin window (UTW) and energydispersive X-ray spectrometer.

\subsection{Batch and continuous adsorption experiments}

The $\mathrm{pH}$ effect was studied at $\mathrm{pH}$ range of 2.0-6.0 since metal precipitation onto its hydroxide takes place at $\mathrm{pH}$ above 6.0. To adjust the $\mathrm{pH}$, appropriate amount of $\mathrm{H}_{2} \mathrm{SO}_{4}$ solution was added to the solution. Batch adsorption experiments were conducted by shaking the Erlenmeyer flasks filled with a mixture of neem leaf powder and copper solution for predetermined period at 30, 50 and $70{ }^{\circ} \mathrm{C}$ in a shaker bath MEMMERT SV-1422. Adsorption isotherm study was carried out with initial Cu(II) concentration of $200 \mathrm{mg} / \mathrm{L}$. The initial $\mathrm{pH}$ value of 5.0 (optimum $\mathrm{pH}$ ) was used for all experiments. The adsorbent dosage is maintained between 0.5 and $2.2 \mathrm{~g}$. $\mathrm{Cu}(\mathrm{II})$ solution was prepared by diluting $0.781 \mathrm{~g}$ of $\mathrm{CuSO}_{4} \cdot 5 \mathrm{H}_{2} \mathrm{O}$ in $1000 \mathrm{~mL}$ distilled water, of which only $50 \mathrm{~mL}$ is used each time. The solution concentration was analyzed by UVVis Genesys $10 \mathrm{v}$ spectrophotometer at $352 \mathrm{~nm}$.

Continuous adsorption experiments were conducted as follow: neem leaf powder was packed in a glass column with a diameter of $1.7 \mathrm{~cm}$ and a height of $10 \mathrm{~cm}$. $\mathrm{Cu}$ (II) solutions was pumped through the column by peristaltic pump (Masterflex 7550-62). This experiment was performed to obtain breakthrough curves at different flow rates ( 8.5 and $9.4 \mathrm{~mL} / \mathrm{min}$ ), feed concentrations ( 400 , 500 and $600 \mathrm{ppm})$ and bed height $(4,5$ and $6 \mathrm{~cm})$. Solutions were collected at the column outlet after each fixed time intervals and analyzed for its copper concentration.

\section{Results and discussion}

\subsection{Characteristic of neem leaf before and after adsorption}

Functional groups on neem leaf powder were analyzed using FTIR. Diverse type of functional groups are available, namely $\mathrm{C}-\mathrm{H}$ bending (985.56-1472.55 $\left.\mathrm{cm}^{-1}\right), \quad \mathrm{C}-\mathrm{H}$ stretching (2845.77-

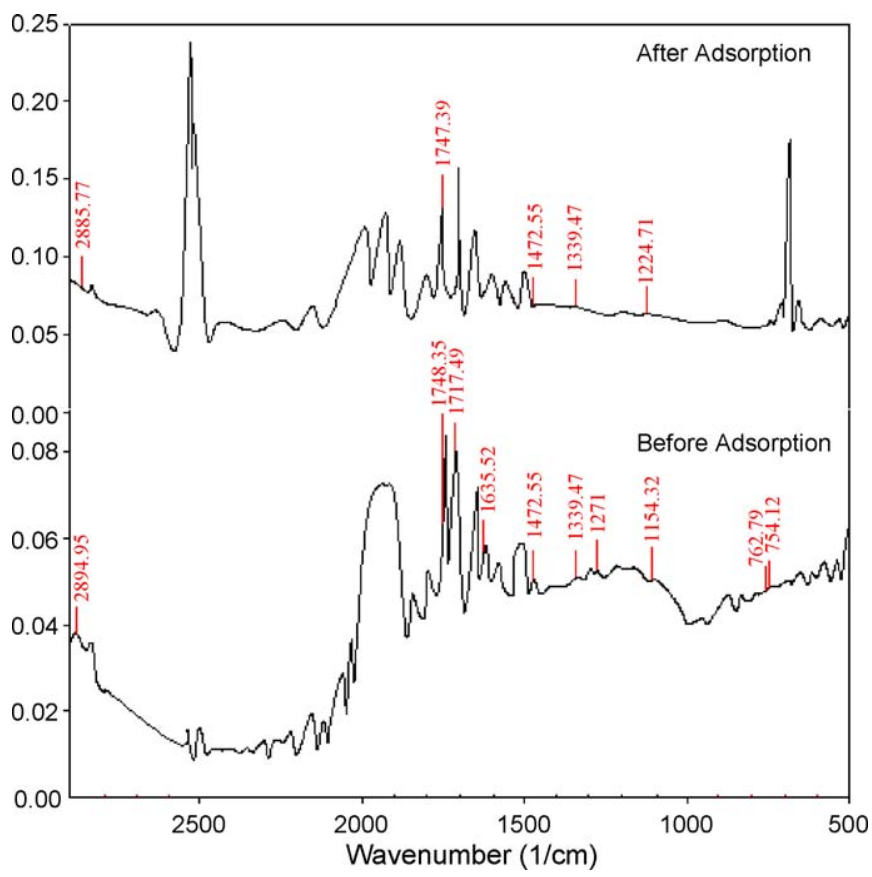

Fig. 1. Fourier transform infra-red (FTIR) spectra of neem leaf powder before and after adsorption.

$\left.2909.42 \mathrm{~cm}^{-1}\right), \mathrm{O}-\mathrm{CH}_{3}\left(1475.12 \mathrm{~cm}^{-1}\right), \mathrm{C}=\mathrm{C}$, ketone $(1575.73-$ $\left.1748.35 \mathrm{~cm}^{-1}\right)$, carboxylic $\left(1319.22-1717.49 \mathrm{~cm}^{-1}\right)$, amides $\left(1575.73 \mathrm{~cm}^{-1}\right)$, aromatic $\left(754.12-762.79 \mathrm{~cm}^{-1}\right), \mathrm{C}-\mathrm{O}-\mathrm{C}$ stretching $\left(1164.92 \mathrm{~cm}^{-1}\right)$, sulfur compounds $\left(1097.42-1339.47 \mathrm{~cm}^{-1}\right)$, alcohols and phenols $\left(1271-3627.85 \mathrm{~cm}^{-1}\right)$. FTIR spectra are depicted in Fig. 1. After sorption, several functional groups which were initially present disappear, while some other had their position altered. For example, on alcohols and phenols group, $\mathrm{O}-\mathrm{H}$ bending was not detected after $\mathrm{Cu}(\mathrm{II})$ sorption, while peaks (a)

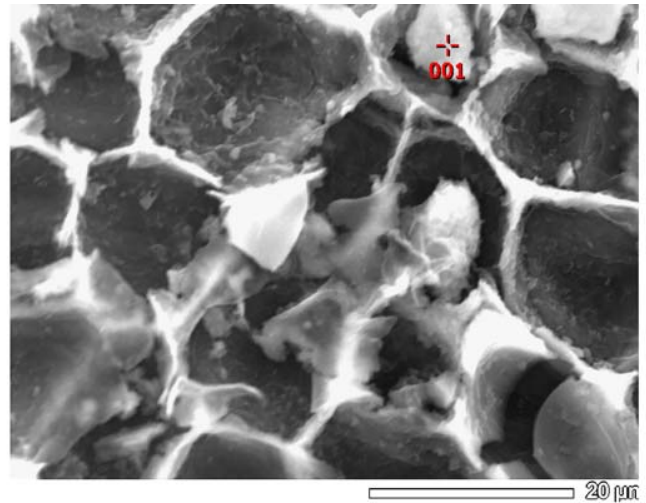

(b)

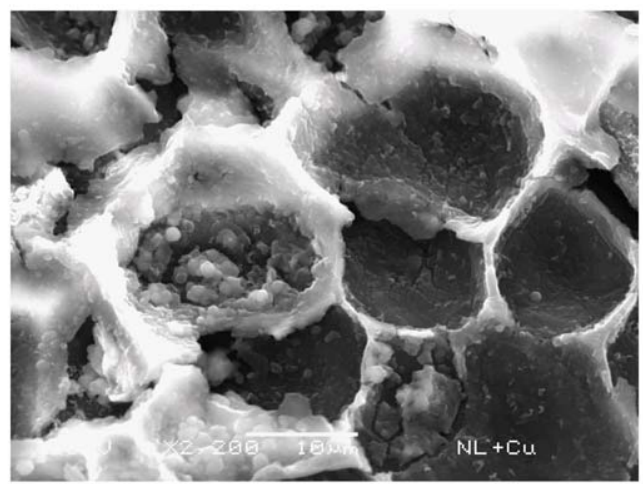

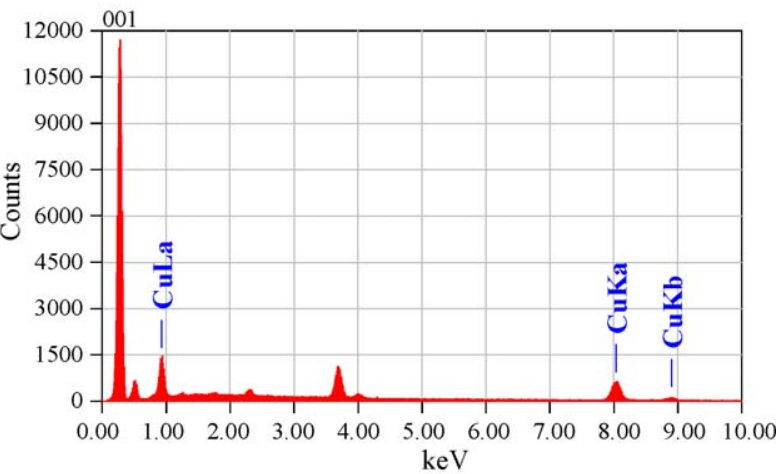

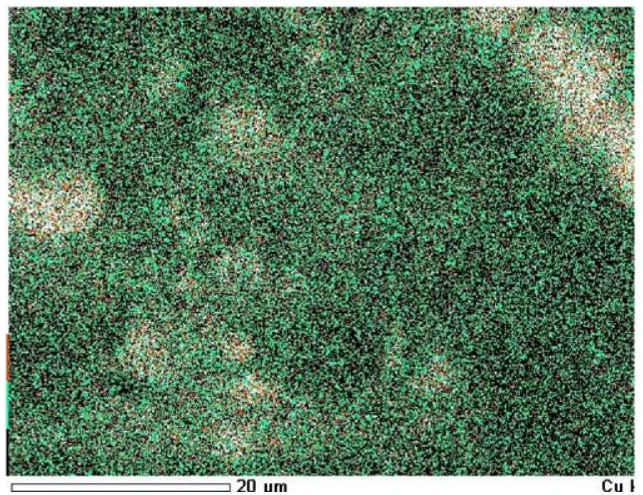

Fig. 2. (a) SEM and EDX spectra of Cu loaded neem leaf powder, (b) SEM and X-ray elemental mapping for Cu on Cu-loaded neem leaf powder. 


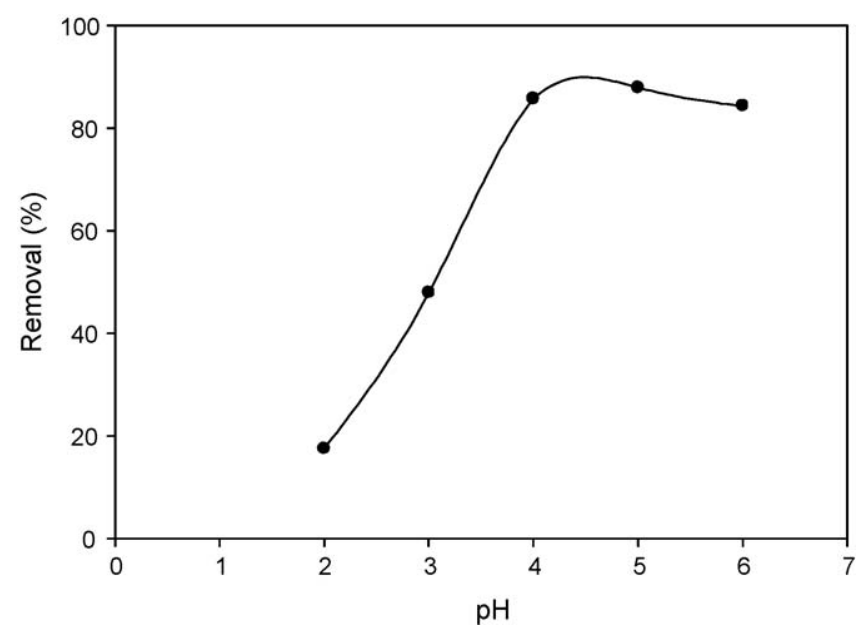

Fig. 3. Effect of solution $\mathrm{pH}$ on the sorption of $\mathrm{Cu}(\mathrm{II})$ on neem leaf $\left(C_{\mathrm{o}}=200 \mathrm{mg} / \mathrm{L}\right.$, and mass of neem leaf $0.5 \mathrm{~g}$ ).

characteristics of $\mathrm{O}-\mathrm{H}$ bending and $\mathrm{C}-\mathrm{O}$ stretching (chelating compounds) shifted from 2894.95 to $2882.42 \mathrm{~cm}^{-1}$. Same tendency were observed for carboxylic groups. Yet, several characteristic bonding such as $\mathrm{C}-\mathrm{H}$ stretching and $\mathrm{S}=\mathrm{O}$ stretching are not influenced by the adsorption process.

Fig. 2(a) shows the SEM-EDX results for neem leaf after copper ion adsorption, on which copper's existence on the surface is confirmed from $\mathrm{Cu} \mathrm{K}$ and $\mathrm{L}$ peaks. SEM and $\mathrm{Cu}$ elemental mapping on a particular surface spot after adsorption is also given in Fig. 2(b). Bright spots indicate copper's presence, of which the copper's distribution was not uniform. This would mean that only some functional groups on the surface were responsible for the copper uptake from the solution.

\subsection{Adsorption studies}

The $\mathrm{pH}_{\mathrm{pzc}}$ of neem leaf is 4.5. $\mathrm{Cu}$ (II) uptake was affected by $\mathrm{pH}$ in the range of 2.0-6.0 as indicated in Fig. 3. At low pH the amount of $\mathrm{Cu}(\mathrm{II})$ uptake was also low and enhanced with increasing $\mathrm{pH}$ from 2.0 to 5.0. The highest percentage removal of $\mathrm{Cu}$ (II) on neem leaf were observed between the $\mathrm{pH} 4.0$ and 6.0. At $\mathrm{pH}<\mathrm{pH}_{\mathrm{pzc}}$, the acidic water donates more protons than hydroxide groups and the surface charge of neem leaf is positive, causing the protons presents in the solution to compete strongly with $\mathrm{Cu}(\mathrm{II})$ ions for the active sites on the surface of neem leaf, resulting in lower amount of $\mathrm{Cu}(\mathrm{II})$ uptake. With $\mathrm{pH}$ rise, electrostatic repulsion between $\mathrm{Cu}$ (II) and surface sites as well as the competing effect of protons decreased which proves to be more beneficial toward $\mathrm{Cu}$ (II) ions uptake.

To correlate the adsorption equilibria data, Langmuir and Freundlich models are employed. Langmuir model has the form of

$q_{e}=q_{\max } \frac{K_{L} C_{e}}{1+K_{L} C_{e}}$

and Freundlich has the form of

$q_{e}=K_{f} C_{e}^{1 / n}$

where $q_{e}$ is the amount adsorbed at equilibrium condition, $q_{\max }$ is the Langmuir constant which is equal to adsorption capacity. $K_{L}$ represents Langmuir sorption equilibrium constant while $C_{e}$ is equilibrium concentration. $K_{F}$ and $n$ on the other hand are Freundlich constants.

Langmuir and Freundlich fitting plots are shown in Fig. 4(a). Its parameters and correlation coefficient values $\left(R^{2}\right)$ are summarized (a)
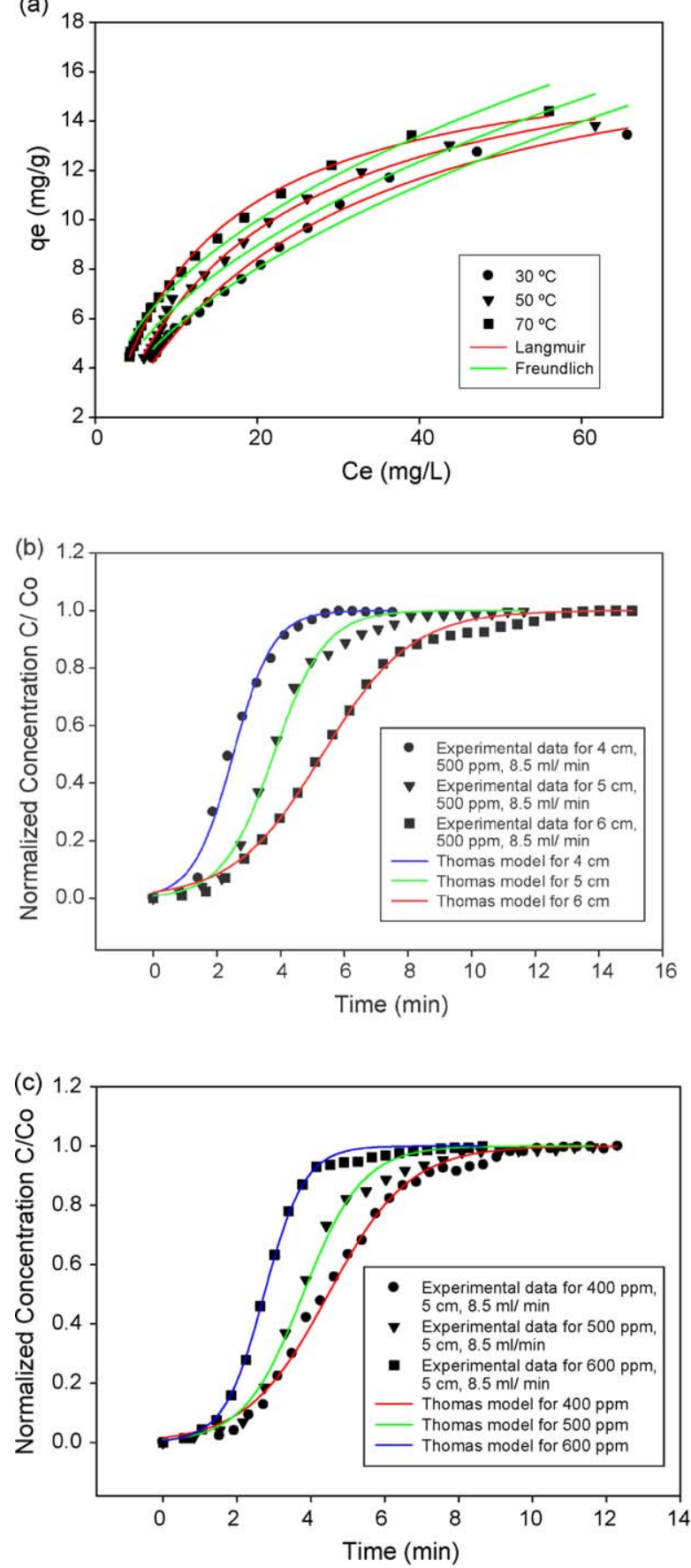

Fig. 4. (a) Biosorption isotherms of copper on neem leaf powder, (b) effect of bed height on the breakthrough curve, (c) effect of concentration on the breakthrough curve.

in Table 1. It is obvious that Langmuir equation fits the data better that Freundlich equation, which is also evidenced by better correlation coefficient value in Table 1 . Freundlich equation fails to predict the adsorption experimental data at high equilibrium concentration due to the inavailability of saturation capacity term in its equation. While $q_{\max }$ (maximum adsorption capacity) increased from $2.85 \times 10^{-4}$ to $2.88 \times 10^{-4} \mathrm{~mol} / \mathrm{g}, K_{L}$ (Langmuir equilibrium constant) was enhanced from 2567 to 5223 (L/mol) along with temperature rose. The enhancement of maximum adsorption capacity $\left(q_{\max }\right)$ as a function of temperature is a strong indication that the chemisorption is the control mechanism. One of the distinct features of the chemisorption is the increase of 
Table 1

Isotherm constants of Freundlich and Langmuir models for sorption process.

\begin{tabular}{|c|c|c|c|c|c|c|c|}
\hline \multirow[t]{2}{*}{ Heavy metal ion } & \multirow[t]{2}{*}{ Temperature $\left({ }^{\circ} \mathrm{C}\right)$} & \multicolumn{3}{|l|}{ Freundlich } & \multicolumn{3}{|l|}{ Langmuir } \\
\hline & & $K_{F}(\mathrm{mg} / \mathrm{g})$ & $N$ & $R^{2}$ & $Q_{\max }(\mathrm{mol} / \mathrm{g}) \times 10^{4}$ & $K_{\mathrm{L}}(\mathrm{L} / \mathrm{mol})$ & $R^{2}$ \\
\hline \multirow[t]{3}{*}{$\mathrm{Cu}^{2+}$} & 30 & 1.78 & 1.99 & 0.975 & 2.84 & 2567 & 0.991 \\
\hline & 50 & 2.24 & 2.16 & 0.961 & 2.86 & 3545 & 0.995 \\
\hline & 70 & 2.78 & 2.35 & 0.978 & 2.88 & 5223 & 0.997 \\
\hline
\end{tabular}

adsorption capacity with temperature. Another indication is the high value of $K_{L}$. The $K_{L}$ value can be correlated with adsorption enthalpy change $\left(\Delta H^{\circ}\right)$. Due to the endothermic nature of chemisorption, $\Delta H^{\circ}$ value would be positive. Therefore, in parallel to temperature increase, $K_{L}$ value should also rise.

Fig. 4(b) shows the breakthrough curve for a fixed initial concentration of $500 \mathrm{mg} / \mathrm{L}$ and flow rate $8.5 \mathrm{~mL} / \mathrm{min}$ with different bed height of 4, 5 and $6 \mathrm{~cm}$. Fig. 4(c), on the other hand displays the breakthrough curve for fixed bed height of $5 \mathrm{~cm}$ and flow rate $8.5 \mathrm{~mL} / \mathrm{min}$ with different initial copper concentration of 400,500 and $600 \mathrm{mg} / \mathrm{L}$. The dynamic column data were fitted by Thomas model to determine the equilibrium specific uptake of copper $\left(q_{0}\right)$ and also its rate constant $\left(K_{T H}\right)$. Thomas model (Thomas, 1944$)$ is defined as

$\frac{C_{t}}{C_{o}}=\frac{1}{1+\exp \left[K_{T H}\left(q_{e} m-C_{o} V_{e f f} / v\right)\right]}$

where $K_{T H}$ is Thomas rate constant, while $C_{t}$ and $C_{o}$ are the concentration of metal in the effluent and influent, respectively. In addition, $V_{\text {eff }}$ is the volume of effluent and $m$ is the mass of biosorbent in the column.

Bed height effect on the breakthrough curves can be clearly seen in Fig. 4(b). The breakthrough time increase as the bed height increases. Furthermore, the amount of cooper ions adsorbed also increases for larger bed height. Accordingly, at larger bed height, the distance for mass transfer zone is longer, resulting in higher value of breakthrough time which is mainly caused by the higher contact time between metal ions solution and neem leaves powder surface. The effect of influent concentrations on the breakthrough curves is also shown in Fig. 4(c). Increasing the influent concentration enhances the total adsorption capacity, hence the breakthrough curve become steeper as the feed concentration increase.

\subsection{Thermodynamic of adsorption}

Free energy change $\left(\Delta G^{\circ}\right)$ is a fundamental criterion of process spontaneity which can be estimated from

$\Delta G^{\circ}=-R T \ln K_{L}$

where $K_{L}$ is equilibrium constant obtained from Langmuir model (L/mol), $T$ is the absolute temperature $(K)$ and $R$ is the gas constant $(8.314 \mathrm{~J} / \mathrm{mol} \mathrm{K})$. The correlation between free energy change, enthalpy change $\left(\Delta H^{\circ}\right)$ and entropy change $\left(\Delta S^{\circ}\right)$ is given by

$\Delta G^{\circ}=\Delta H^{\circ}-T \Delta S^{\circ}$

The values of $\Delta G^{\circ}$ obtained at 30,50 and $70{ }^{\circ} \mathrm{C}$ are $-19.78,-21.96$, and $-24.42 \mathrm{~kJ} / \mathrm{mol}$, respectively. Negative values of $\Delta G^{\circ}$ denotes the spontaneity nature of the adsorption (Ho and Ofomaja, 2006). A positive $\Delta H^{\circ}$ value $(15.43 \mathrm{~kJ} / \mathrm{mol})$ indicates that the process is endothermic as well as suggesting the high probability for chemisorption as the controlling mechanism. Additionally, positive value of $\Delta S^{\circ}(0.116 \mathrm{~kJ} / \mathrm{mol} \mathrm{K})$ indicates that the process is irreversible which again is the characteristic of chemisorption (Aksu and Tunc, 2005).

\section{Conclusion}

This study probes the performance of neem leaf biomass waste to sequester copper from aqueous solution. Neem leaf serves as a potential alternative adsorbent to remove copper ions from copper containing solution. The adsorption experiments were conducted in batch and dynamic modes at optimum $\mathrm{pH}$ of 5 . Adsorption equilibria data were also fitted by the well-known adsorption models, Freundlich and Langmuir. Langmuir equation represents the adsorption equilibria better than Freundlich. Thermodynamics data indicated that the adsorption of copper ion onto neem leaf is endothermic. Chemisorption can be pointed out as the controlling mechanism. Carboxylic groups, alcohols and phenols were involved in the binding process. Lastly, the dynamic data was also provided in the form of breakthrough curve along with Thomas model representation.

\section{Acknowledgements}

The authors would like to thank A/Prof. João C. Diniz da Costa from FIMLab, Division of Chemical Engineering, the University of Queensland, Australia for his support in terms of SEM equipment access.

\section{References}

Aksu, Z. and O. Tunc, "Application of Biosorption for Penicillin G Removal: Comparison with Activated Carbon,” Process Biochem., 40, 831 (2005).

Aksu, Z. and G. Donmez, "Binary Biosorption of Cadmium(II) and Nickel(II) onto Dried Chlorella vulgaris: Co-Ion Effect on Mono-Component Isotherm Parameters," Process Biochem., 41, 860 (2006).

Al-Rub, F. A. A., "Biosorption of Zinc on Palm Tree Leaves: Equilibrium, Kinetics, and Thermodynamics Studies," Sep. Sci. Technol., 41, 3499 (2006).

Bhattacharyya, K. G. and A. Sharma, "Adsorption of $\mathrm{Pb}(\mathrm{II})$ from Aqueous Solution by Azadirachta indica (Neem) Leaf Powder," J. Hazard. Mater., B113, 97 (2004).

Ho, Y. S. and A. E. Ofomaja, "Biosorption Thermodynamics of Cadmium on Coconut Copra meal as Biosorbent," Biochem. Eng. J., 30, 117 (2006).

Kang, S., J. Lee, and K. Kima, "Biosorption of $\mathrm{Cr}(\mathrm{III})$ and $\mathrm{Cr}(\mathrm{VI})$ onto the Cell Surface of Pseudomonas aeruginosa," Biochem. Eng. J., 36, 54 (2007)

Mungasavalli, D. P., T. Viraraghavan, and Y. C. Jin, "Biosorption of Chromium from Aqueous Solutions by Pretreated Aspergillus niger: Batch and Column Studies," Colloids Surf. A: Physicochem. Eng. Aspects, 301, 214 (2007).

Sharma, A. and K. G. Bhattacharyya, "Azadirachta indica (Neem) Leaf Powder as a Biosorbent for Removal of Cd(II) from Aqueous Medium," J. Hazard. Mater., B125 102 (2005).

Thomas, H. C., "Heterogeneous Ion Exchange in a Flowing System," J. Am. Chem. Soc. 66, 1664 (1944).

Wibowo, N., L. Setyadhi, D. Wibowo, and J. Setiawan, "Adsorption Benzene and Toluene from Aqueous Solutions onto Activated Carbon and Its Acid and Heat Treated Forms: Influence of Surface Chemistry on Adsorption," J. Hazard. Mater., 146, 237 (2007) 